\title{
PENDIDIKAN KESEHATAN TENTANG DIABETES MELITUS PADA KELUARGA DI KELURAHAN PAHANDUT PALANGKARAYA
}

\author{
Putria Carolina $^{1}$, Haryadi ${ }^{2}$, Wawan Kurniawan Setiawan ${ }^{3}$, Meyria Sintani $^{3}$, Yuliani ${ }^{3}$, Orien \\ Cantona $^{3}$, Roby Kristian ${ }^{3}, \mathrm{Niko}^{3}$, Rosalia ${ }^{3}$ \\ ${ }^{1}$ Dosen PengajarProgram Studi S-1 Keperawatan \\ ${ }^{2}$ Perawat PuskesmasPahandutPalangka Raya \\ ${ }^{3}$ Mahasiswa Program ProfesiNers
}

\section{Sekolah Tinggi Ilmu Kesehatan Eka Harap Palangka Raya}

\section{Email: putria_ekaharap@yahoo.co.id}

Diabtes Melitus (DM) adalah suatu penyakit yang ditandai dengan kadar glukosa darah melebihi normal yang ditandai dengan hiperglikemia puasa dan postprandial, aterosklerosis dan penyakit vaskular mikroangiopati. DM dapat disebabkan karena pola makan atau factor genetik. Penelitian yang dilakukan di Kelurahan Pahandut Palangka Raya menunjukkan kurangnya pengetahuan keluarga (67\%) mengena ipenyakit DM dapat menjadi factor predisposisi terjadinya DM pada anggota keluarga.Pendidkan adalah upaya agar masyarakat berperilaku atau mengadopsi perilaku kesehatan dengan cara persuasi, bujukan, imbauan, ajakan, memberi informasi, memberi kesadaran dan sebagainya, melalui kegiatan yang disebut pendidikan atau promosi kesehatan.

Metode pelaksanaan kegiatan adalah dengan menggunakan strategi pendidikan kesehatan bagi keluarga di Kelurahan Pahandut Palangka Raya. Kegiatan yang dilakukan adalah dengan melaksanakan pendidikan kesehatan kepada keluarga di Kelurahan Pahandut Palangka Raya. Kegiatan dilaksanakan dengan metode ceramah dan Tanya jawab. Media pendidikan kesehatan yang digunkan adalah dengan LCD proyek tordan leaflet yang dibagikan kepada keluarga. Materi yang diberikan adalah mengenai penyakit DM yang meliputi pengertian, penyebab, tanda dan gejala, penanganan, komplikasi. Selama pendidikan kesehatan berjalan, lingkungan kondusif, keluarga antusias mendengarkan pendidikan kesehatan dan aktif bertanya saatd iberikan kesempatan untuk diskusi.Hasil evaluasi pendidikan kesehatan menunjukkan keluarga mampu untuk menyebutkan dan menjelaskan kembali mengenai penyakit DM seperti yang dipaparkan pada saat pendidikan kesehatan.

Kegiatan pengabdian masyarakat yang dilakukan oleh dosen, perawat dan mahasiswa profesi Nerske pada keluarga di Kelurahan Pahandut Palangka Raya dapat dinyatakan berhasil. Melalui hasil evaluasi selama pendidikan kesehatan berlangsung yaitu adanya respon yang positif dari keluarga dan juga mampu untuk menyebutkan kembali mengenai penyakit DM seperti yang telah dipaparkan.

Kata Kunci: Pendidikan Kesehatan, Diabetes Melitus, Keluarga 


\begin{abstract}
Diabtes Melitus (DM) is a disease characterized by blood glucose levels exceeding normal which is characterized by fasting and postprandial hyperglycemia, atherosclerosis and microangiopathic vascular disease. DM can be caused due to diet or genetic factors. Research conducted in Pahandut Palangka Raya Village showed a lack of family knowledge (67\%) regarding DM can be a predisposing factor for the occurrence of DM in family members. Education is an effort to make people behave or adopt health behaviors by means of persuasion, persuasion, appeal, invitation, giving information, giving awareness and so on, through activities called education or health promotion.

The method of implementing the activity is to use a health education strategy for families in Pahandut Palangka Raya. The activities carried out are by carrying out health education to families in Pahandut Palangka Raya. The activity is carried out with the lecture and question and answer method. The health education media used are LCD projectors and leaflets distributed to families. The material provided is about DM disease which includes understanding, causes, signs and symptoms, treatment, complications. During health education, the environment is conducive, the family enthusiastically listens to health education and actively asks when given opportunities for discussion. The results of the evaluation of health education show the family is able to mention and explain again about DM disease as described during health education. Community service activities carried out by lecturers, nurses and Ners professional students to families in Pahandut Palangka Raya can be declared successful. Through the evaluation results during health education, there is a positive response from the family and is also able to mention again about DM as described.
\end{abstract}

Keywords: Health Education, Diabetes Melitus, Family

\section{PENDAHULUAN}

Diabetes mellitus merupakan kelainan defisiensi atau resistensi insulin yang absolute atau relative ditandai oleh gangguan metabolisme karbohidrat protein dan lemak[1]. Gejala yang timbul adalah akibat kurangnya sekresi insulin atau ada insulin yang dikaitkan dengan gangguan mikrovaskular dan makrovaskular, gangguan neuropatik dan lesi dermopatik.

Tahun 2012 dilaporkan bahwa terdapat 1,5 juta penduduk mengalami kematian akibat DM dengan prevalensi sekitar 2,7\% Seluruh kematian akibat DM di dunia, 70\% kematian terjadi di negara-negara berkembang termasuk Indonesia. Tingkat prevalensi global penderita DM pada tahun 2014 sebesar $8,3 \%$ dari keseluruhan penduduk di dunia dan mengalami peningkatan pada tahun 2014 menjadi 387juta kasus. Tahun 2013, proporsi penduduk Indonesia yang berusia $\geq 15$ tahun dengan DM adalah 6,9 persen. Prevalensi DM yang terdiagnosis dokter tertinggi terdapat di DI Yogyakarta (3,0\%) dari 2.777.211 jumlah penduduk, DKI Jakarta (3,0\%), dari 7.609.272 jumlah penduduk, Sulawesi Utara $(2,4 \%)$ dari 1.698.831 jumlah penduduk dan Kalimantan Timur (2,3\%), dari 2.753.491 jumlah penduduk. Data daerah Kalimantan Tengah $(1,2 \%)$ dari 1.608.217 jumlah penduduk sudah terdiagnosis dokter dan $(0,4 \%)$ belum pernah terdiagnosis DM oleh dokter tetapi dalam 1 
bulan terkhir mengalami gejala sering lapar, sering haus, sering buang air kecil dalam jumlah banyak dan berat badan turun [3].

Berdasarkan hasil survey pendahuluan yang dilakukan melalui wawancara pada 10 keluarga di Kelurahan Pahandut Palangka Raya terdapat $8(80 \%)$ keluarga memiliki pengetahuan yang kurang tentang DM dan 2 $(20 \%)$ keluarga memiliki pengetahuan yang cukup tentang DM.

DM merupakan kelainan defisiensi atau resistensi insulin yang absolute atau relative ditandai oleh gangguan metabolisme karbohidrat protein dan lemak. Ketidaktahuan masyarakat tentang penyakit DM menyebabkan banyak masyarakat yang barumengetahui menderita penyakit DM setelah melakukan pemeriksaan di rumah sakit dan oleh dokter terdiagnosis menderita penyakit DM. Berpedoman pada pencegahan jauh lebih baik dari pada pengobatan, sudah selayaknya pencegahan DM harus mendapat perhatian. Salah satu cara yang terbaik untuk pencegahan ialah meningkatkan pengetahuan melalui pendidikan kesehatan bagi keluarga.

Pendidikan kesehatan tersebut dapat menambah pengetahuan keluarga untuk mengetahui penyakit DM. Dalam penatalaksanaan DM terdapat lima pilar diantaranya diet, latihan, pemantauan, terapi dan pendidikan. Jika keluarga tidak mengetahui penyakit DM, penyebab, faktor resiko terkena $\mathrm{DM}$, tanda dan gejala, cara pencegahan, dan penanganan DM, maka angka kejadian penyakit DM akan terus meningkat dari tahun-ketahun. Pendidikan kesehatan adalah suatu proses perubahan pada diri manusia yang ada hubungannya dengan tercapainya tujuan kesehatan perorangan, keluarga atau masyarakat. Menurut Prof. Dr. M.J Langevelt, pendidikan adalah setiap usaha, pengaruh, perlindungan, dan bantuan yang dilakukan pada anak untuk menjadi dewasa. Ciri orang dewasa ditunjukkan oleh kemampuan secara fisik, mental, moral, sosial, dan emosional. Berdasarkan GBHN (Garis-Garis Besar Haluan Negara), pendidikan adalah usaha sadar unruk mengembangkan kepribadian dan kemampuan di dalam dan diluar sekolah yang berlangsung seumur hidup [4].

Perawat memiliki peran yang penting dalam membantu masyarakat mencegah DM yaitu melalui upaya preventif dan promotif.

Perawat memiliki peran untuk melakukan pencegah dini terhadap gangguan sistem endokrin terutama masalah DM. Dalam pengertian yang sangat luas, preventif diartikan sebagai upaya secara sengaja dilakukan untuk mencegah terjadinya gangguan, kerusakan, atau kerugian bagi seseorang atau masyarakat sedangkan promotif, perawat memberikan sosialisasi dan promosi kesehatan tentang pentingnya mengetahui, memahami penyakit DM untuk mencegah DM.

\section{METODE PENELITIAN}

Metode pelaksanaan kegiatan pengabdian masyatakat yang dilakukan adalah melalui pendidikan kesehatan yang 
diberikan pada keluarga di Kelurahan Pahandut Kota Palangka Raya.Kegiatan ini dilakukan pada bulan November tahun 2017.Tujuan pelaksanaan kegiatan ini adalah menjadikan kesehatan sebagai sesuatu yang bernilai dikeluarga, mengarahkan cara-cara hidup sehat menjadi kebiasaan hidup seharihari, menolong keluarga agar mampu secara mandiri mengadakan kegiatan untuk mencapai tujuan hidup sehat.Sasaran primer dari kegiatan ini adalah keluarga, yang merupakan unit terkecil masyarakat.Guna mencapai perilaku sehat masyarakat, maka harus dimulai pada tatanan keluarga.Keluarga adalah tempat persemaian manusia sebagai anggota masyarakat, bila persemaian itu jelek maka jelas akan berpengaruh pada masyarakat. Sasaran sekunder adalah para kader kesehatan di wilayah tempat tinggal keluarga.Ruang lingkup kegiatan ini adalah pada upaya peningkatan kesehatan melalui kegiatan preventif dan promotif yaitu pelayanan bagi keluarga yang sehat, agar tetap sehat dan bahkan meningkat status kesehatannya.

Metode pendidikan kesehatan yang digunakan adalah dengan ceramah dan Tanya jawab. Media yang digunakan adalah dengan LCD proyek tordan leaflet yang dibagikan kepada keluarga yang mengikuti pendidikan kesehatan. Pelaksana kegiatan pendidikan kesehatan adalah tim pengabdian masyarakat dari STIKes Eka Harap yang terdiri dari edukator, fasilitatitor, observer, notulis, dokumentator.

\section{HASIL DAN PEMBAHASAN}

Kegiatan pengabdian masyarakat ini dilakukan sebagai kontribusi institusi pendidikan dalam upaya turut serta meningkatkan derajat kesehatan masyarakat khususnya di Kelurahan Pahandut Kota Palangka Raya. Kegiatan yang dilakukan oleh tim pengabdian masyarakat berjalan dengan baik dan mendapat respon yang positif dari keluarga. Keluarga yang hadir dalam kegiatan pendidikan kesehatan adalah sebanyak 35 orang.

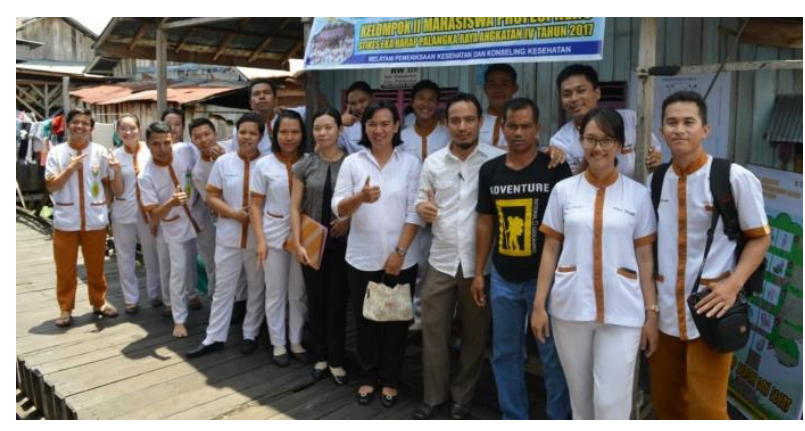

Gambar 1. Tim Pengabdian Masyarakat STIKes Eka Harap Palangka Raya.

Edukasi yang diberikan pada kegiatan pendidikan kesehatan ini mengenai penyakit DM yang meliputi pengertian, penyebab, tanda dan gejala, penanganan, komplikasi. Tahap kegiatan yang dilakukan oleh tim dengan masing-masing tugasnya adalah sebaga iberikut:

1. Kegiatan pertama yang dilakukan oleh educator adalah membuka kegiatan dengan memberikan salam pembuka, memperkenalkan diri dan tim, menyampaikan maksud dan tujuan kegiatan pendidikan kesehatan dan melakukan kontrak waktu dengan peserta. 


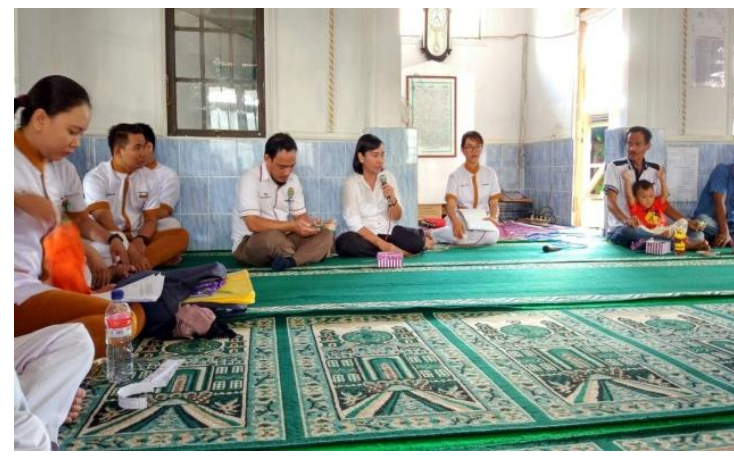

Gambar 2.Kegiatan Pembukaan

2. Selanjutnya educator menyajikan materi pendidikan kesehatan dengan metode memberikan ceramah selama 30 menit kepada keluarga. Media yang digunakan oleh educator selama menyajikan materi adalah dengan LCD Proyektor. Posisi educator beradadi depan menghadap keluarga yang hadir, sesekali berjalan mendekati barisan duduk peserta.

3. Setelah educator selesai menyajikan materi, selanjutnya adalah sesi Tanya jawab dan diskusi selama 30 menit. Selama kegiatan diskusi berlangsung, fasilitator sangat berperan aktif untuk merangsang peserta agar aktif bertanya mengenai topik yang sedang dibahas.Selama kegiatan berlangsung fasilitator duduk menyebar bersama dengan peserta kegiatan. Peserta sangat antusias dengan materi yang diberikan, mereka mengungkapkan sangat bermanfaat karena sebelumnya tidak terlalu mengetahui terkait penyakit DM.

4. Sesi akhir dari kegiatan adalah feed back yang diberikan oleh edukator. Memberikan apresiasi kepada peserta karena telah mengikuti kegiatan dengan tertib dan antusias untuk bertanya.

5. Selama kegiatan berlangsung, observer memiliki tugas untuk melakukan pengamatan terhadap jalannya kegiatan dan mencatatnya. Notulis melaksanakan kegiatan pencatatan kejadian-kejadian yang berlangsung yaitu bagaimana peran dari tim, peserta dan lingkungan sekitar. Sedangkan dokumentator adalah melakukan dokumentasi selama kegiatan berlangsung dengan media kamera.

6. Kegiatan terakhir adalah penutup, educator menutup kegiatan.

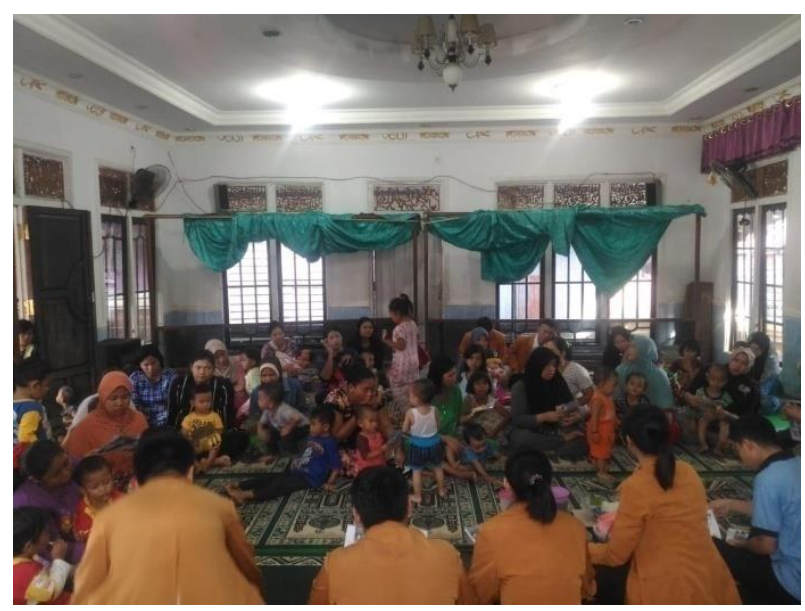

Gambar 3.PelaksanaanKegiatan

Pengetahuan adalah hasil penginderaan manusia, atau hasil tahu seseorang terhadap objek melalui indera yang dimilikinya (mata, hidung, telinga dan sebagainya). Dengan sendirinya pada waktu penginderaan sampai menghasilkan pengetahuan tersebut sangat dipengaruhi oleh intensitas perhatian dan persepsi terhadap objek. Sebagian besar pengetahuan seseorang diperoleh melalui indera pendengaran (telinga), dan indera 
penglihatan (mata). Pengetahuan seseorang terhadap objek mempunyai intensitas atau tingkat yang berbeda-beda [5].

Peningkatan pengetahuan tidak mutlak diperoleh di pendidikan formal, akan tetapi juga dapat diperoleh pada pendidikan nonformal. Pengetahuan seseorang tentang sesuatu objek juga mengandung dua aspek yaitu aspek positif dan negatif. Kedua aspek inilah yang akhirnya akan menentukan sikap seseorang terhadap objek tertentu. Semakin banyak aspek positif dari objek yang diketahui, maka akan menumbuhkan sikap makin positif terhadap objek tersebut.

Informasi merupakan sesuatu yang dapat diketahui oleh seseorang untuk meningkatkan pengetahuan, namun ada pula yang menekankan informasi sebagai transfer pengetahuan. Selain itu, informasi juga dapat didefinisikan sebagai suatu teknik untuk mengumpulkan, menyiapkan, menyimpan, memanipulasi, mengumumkan, menganalisis, dan menyebarkan informasi dengan tujuan tertentu.

Informasi yang diperoleh baik dari pendidikan formal maupun nonformal dapat memberikan pengaruh jangka pendek (immediate impact) sehingga menghasilkan perubahan atau peningkatan pengetahuan. Berkembangnya teknologi akan menyediakan bermacam-macam media massa yang dapat memengaruhi pengetahuan masyarakat tentang inovasi baru. Dalam penyampaian informasi sebagai tugas pokoknya, media massa juga membawa pesan-pesan yang berisi sugesti yang dapat mengarahkan opini seseorang. Adanya informasi baru mengenai sesuatu hal memberikan landasan kognitif baru bagi terbentuknya pengetahuan terhadap hal tersebut.

\section{KESIMPULAN}

Hasil pengabdian masyarakat ini dapat menjadi sumber informasi bagi petugas kesehatan terutama perawat dalam memberikan asuhan keperawatan pada tatanan komunitas terkait pendidikan kesehatan tentang Diabetes Melitus. Sebaiknya kegiatan ini dilakukan secara rutin oleh petugas kesehatan sebagai tindak lanjut bagi masyarakat dalam rangka meningkatkan derajat kesehatan yang optimal.

\section{Daftar Pustaka}

1. Hartono, Andri. 2012. Buku saku keperawatan pasien dengan gangguan fungsi endokrin. Tenggerang selatan. Binarupa Aksara.

2. Baradero, Mary, dkk. 2009. Seri Asuhan Keperawtan Klien Gangguan Endokrin. Jakarta EGC

3. Budiman \& Agus. 2013. Kapita Selekta Kuesioner.Jakarta: Salemba Medika

4. Dalimartha Setiawan, Adrian Felix. 2014. Makanan dan Herbal Untuk Penderita Diabetes Mellitus. Jakarta: Penebar Swadaya.

5. Kemenkes riset kesehatan dasar: Riskesdas. 2013. Badan Penelitian Dan Pengembangan Kesehatan Kementrian RI. Jakarta

6. Maulana. 2009. Promosi Kesehatan. Jakarta: EGC.

7. Notoatmodjo. 2007. Promosi kesehatan ilmu perilakuJakarta. Rineka Cipta

8. Notoadmojo.2010. Promosi Kesehatan Dan perilaku Kesehatan. Jakarta: PT. Rineka Cipta. 
Putria Carolina, Haryadi, Wawan Kurniawan Setiawan, Meyria Sintani, Yuliani, Orien Cantona, Roby Kristian, Niko, Rosalia

9. Notoadmojo.2012. Promosi Kesehatan Dan perilaku Kesehatan. Jakarta: PT. Rineka Cipta

10. Smeltzer and Bare. 2002. Buku Ajar Keperawatan Medikal Bedah Edisi 8 vol. 2.Soegondo, Sidartawan, dkk. 2009. Penatalaksaan diabetes mellitus terpadu. Jakarta: Balai Penerbitan FKUI. 